\title{
Strategic Management and Performance Measurement - A Connected or Disconnected Duo? Evidences from Croatian Public Administration
}

\author{
Romea Manojlović* \\ Faculty of Law, University of Zagreb; Zagreb, Croatia \\ romea.manojlovic@pravo.hr
}

\section{ABSTRACT}

The paper examines the link between strategic management and performance measurement in the public sector. The main hypothesis is that the stages of strategic management development are positively correlated with the number of performance dimensions measured by public organisations. In order to examine the stated hypothesis results from the empirical research conducted in Croatian public administration are being presented. A questionnaire has been sent to 253 central and local organisations and additional interviews have been conducted. The results confirm the hypothesis and determine that the enhancement of strategic planning and management is one of the main stimuli for performance measurement in Croatia.

Keywords: strategic management, strategic planning, performance measurement, performance dimensions, Croatia

JEL: 021,038

\section{Introduction}

Strategic management and performance measurement are managerial instruments whose implementation in the public sector has augmented since the late 1970s and the beginning of 1980s, which were marked by the origin of the new and influential doctrine of New Public Management (NPM). The basic premises of NPM were the adoption of private sector management tools in the public sector and the convergence of private and public sector management (s. McLaughlin et al., 2002). Among other things, NPM put great emphasis on performance measurement as well as on strategic planning and management (Gruening, 2001, p. 2).

* The paper was presented at the 2015 EGPA Conference in Toulouse. The author is grateful for all the comments received. The chapters two was developed by the author in the course of scientific project 'New Croatian Legal System' conducted by the Faculty of Law, University of Zagreb. 
Although both instruments are being implemented, they are mostly treated separately in public management literature (Poister, 2010, p. 252). Hence, the basic goal of this paper is to empirically examine the relationship between strategic management and performance measurement. More precisely, the paper examines whether the stages of strategic management development have influence on the number of performance dimensions measured by public organisations. In order to examine the stated hypothesis results from empirical research conducted in Croatian public administration are being presented.

The next chapter describes the stages strategic management development, the connection between strategic management and performance measurement and sets the main research hypothesis. In the third chapter, research methodology and results are being presented while the last chapters discuss the main findings and offer some conclusions.

\section{Research Variables - Stages of Strategic Management Development and Performance Dimensions}

\subsection{Stages of Strategic Management Development}

As Vizant and Vizant (1996, p. 140) sustain, there is confusion and misconception about what strategic management actually is. Some authors consider strategic management and strategic planning to be overlapping terms (Goldsmith, 1997, p. 31 in Perko Šeparović, 2006, p. 104); however, this is not the case.

Strategic planning is defined by Bryson as a 'disciplined effort to produce fundamental decisions and actions that shape and guide what an organisation is, what it does and why it doesit' (Bryson, 1995, pp. 4-5). Strategic management is said to be the management of the big picture (Kreitner, 2008, p. 181). It encompasses not only the strategic planning process but also resources allocation as well as control and evaluation (Vizant \& Vizant, 1996, p. 140). ${ }^{1}$ Thus, strategic planning is the basic component of strategic management, but strategic management encompasses also all the other managerial functions in the organisation. ${ }^{2}$ Taking on the definition given by Poister (2003, p. 165), in the public sector strategic management needs to incorporate the strategic planning process with the budgeting process, performance appraisal of civil servants and organisational performance measurement and tide them together in a coherent manner. The task of strategic management is to integrate all the processes in the organisation with the basic purpose

1 Using the literature coming from private sector, Kreitner (2008, p. 181) states that strategic management consists of strategic planning, its implementation and control.

2 The well known definition of managerial functions is given by L. Gulick (1937) using the POSDCORB acronym ( $\mathrm{P}=$ planning, $\mathrm{O}=$ organising, $\mathrm{S}=$ staffing, $\mathrm{D}=$ directing, $\mathrm{CO}=$ coordinating, $\mathrm{R}=$ reporting, $\mathrm{B}=$ budgeting); for this and other definitions of managerial functions s. Koprić et al. (2014, pp. 114-115). 
of assuring systematic, coherent and effective achievement of the set strategic goals (Poister \& Streib, 1999, p. 308). ${ }^{3}$

However, as Vizant and Vizant (1996, p. 140) state: 'one major difficulty in the study of strategic management in public organisations is the virtual absence of a definition of successful implementation', meaning that it is hard to identify whether certain organisation has evolved from simple strategic planning towards the full strategic management.

In this paper, Poister's (2003, p. 165) definition of strategic management is being combined with Vizant and Vizant's (1996, p. 141) four levels of strategic management implementation ${ }^{4}$ and following stages of strategic management development are being formulated and operationalised:

- The first one is the simple enactment of strategic plan in which the organisation has produced the strategic plan, but no actions for its implementation, control and evaluation are being taken. ${ }^{5}$

- The second stage is those of proper strategic planning. In this phase the entire circle of strategic planning process is being conducted and strategic plan is being implemented and its execution is being monitored. ${ }^{6}$

- The third and final stage is the proper strategic management. In this phase, apart from all the elements present in the previous stages, organisational budget is linked to the strategic plan. Moreover, this phase is characterised by the linking of all performance measurement systems, including performance appraisal, with strategic plans. ${ }^{7}$

3 For a literature review on strategic planning and management, s. Poister \& Streib (2005).

4 Shortly, the Vizant and Vizant's (1996, p. 1414) four levels are the following: the first level is the completion of strategic planning process. The second level is the production of strategic planning document. The third includes the level two plus changes in the resource allocation process. The last level contains all the aforementioned elements plus changes in the control and evaluation processes. In this paper the first two levels have been inverted, while the last two have been combined and expanded with elements coming from Poister's $(2003, \mathrm{p} .165)$ definition.

5 In this paper, this stage is operationalised as the pure existence of strategic plan; $s$. Appendix 1.

6 In this research, this stage is operationalised by: a) the existence of strategic plan with indicators according to which its implementation can be monitored, b) existence of reports on strategic plan execution (whether at the end of strategic planning period or annually), c) regular meetings on strategic plan implementation. These three elements show that strategic plan is a 'living' document, and that actions are being taken in order to obtain feedback on its implementation.

Bryson (1995, p. 36) states that action plans should be enacted in order for strategic plans' to be effectively implemented. According to Blackerby (1994 in Perko-Šeparović, 2006, p. 107) operational (tactic) plan should be enacted in order to explain how certain larger strategic goal will be achieved. In this paper, this component of strategic planning process is operationalised as the d) existence of annual working plans and e) existence of annual working reports that are connected to the strategic plan. Namely, the connection of annual working plans and annual working reports with the strategic plan should assure that strategic plan is being translated into the everyday work and thus implemented and its implementation controlled. Of course, strategic planning, annual planning as well as budget planning are different types of planning, but strategic management requires them to be connected in order to assure the coherence of the system (s. Poister, 2003, p. 165); s. Appendix 1.

7 In this paper, the last stage is operationalised by a) linking the budget to the strategic plan. This does not mean that in the previous stage resources have not been given for strategic plan execution (this is an indispensable element of strategic planning), but in this phase 


\subsection{Performance Measurement and Performance Dimensions}

Performance measurement can be defined as a number of activities used to obtain information on a variety of performance dimensions, or as Van Dooren et al. (2015, p. 32) put it 'performance measurement is the bundle of deliberate activities of quantifying performance'. However, when speaking about performance it is important to notice that performance is "one of the most important as well as ambiguous concepts in the academic public management debate" (Siegel \& Summermatter, 2008, p. 2). Siegel and Summermatter (2008) have identified different performance dimensions (input, throughput, output, outcome, efficiency, effectiveness, additional types of ratios, requirements, quality, stakeholder-related aspects, value and ethical aspects) and asserted that outputs and outcomes are the most used performance dimensions, but there is no final definition, as well as there is no final agreement about what each of this dimension is. That is why they suggest authors to make clear what is understood under the term performance and to use the comprehensive definition.

Thus, in this paper performance is understood as the achievement of expected outputs and outcomes in relation to the resources used to achieve them (efficiency and cost-effectiveness). Following this definition, four performance dimensions are being examined: ${ }^{8}$

- outputs - concrete results produced by the organisation over which the organisation has control;

- outcomes - effects produced by the organisation on which the environment has an impact; Bouckaert and Halligan (2008, p. 16) state that the public sector has to be oriented towards long-term outcomes;

- efficiency - ratio between inputs and outputs; ${ }^{9}$

- cost-effectiveness - ration between inputs and outcomes. ${ }^{10}$

\subsection{Setting the Hypothesis}

Since the future of public management points to the necessity of linking strategic management with performance measurement and management (Poister, 2010), the basic goal of this paper is to examine whether stages

strategic plan is the guiding element in the entire budgeting process. In addition, this stage is characterised by b) taking the strategic plan into consideration in the decision making process and d) connecting the strategic plan to civil servants' annual working plans, which altogether assures that strategic plan is the guiding document also in the human resource management process; s. Appendix 1.

8 For detailed explanations of these dimensions, as well as additional dimensions, s. Van Dooren et al. (2015, pp. 20-30).

9 Since efficiency is the ratio between inputs and outputs, different types of ratios can be measured (for example, ratio between input in the sense of human resources work and obtained outputs, ratio between costs of inputs and obtained outputs, ratio between inputs in the sense of equipment used and obtained outputs, etc.). However, in this paper, this distinction has not been implemented and all types of ratio between input and outputs are taken into consideration.

10 As with the efficiency, in this paper no distinction between different kinds of ratios between inputs and outcomes has been made. 
of strategic management development have influence on performance measurement; precisely, whether the passing to a more mature stage of strategic management can stimulate the measurement of greater number of performance dimensions (output, outcomes, efficiency, cost-effectiveness).

Looking at the three stages of strategic management development it is possible to presume that the first stage, the pure enactment of strategic plan does not need to bring to any measurement. The plan exists but there is no monitoring of its execution and by the consequence, it does not stimulate any measurement. The second stage, the implementation of the entire strategic planning cycle should stimulate at least outputs and outcomes measurement since they are indispensable for future planning. The proper strategic management, which connects strategic planning with budget and human resource cycle, should stimulate also efficiency and cost-effectiveness measurement. ${ }^{11}$ Starting from these premises the following hypothesis can be formulated:

$H$ : The stages of strategic management development are positively correlated with the number of performance measures.

\section{Empirical Research - Methodology and Results}

\subsection{Methodology}

In order to test the set hypothesis the empirical research in Croatian public administration has been conducted. A questionnaire has been sent to three types of central state organisations: all ministries (20), other central state administrative bodies (34), central level agencies (76); and to the three types of local level organisation: second level units of local self-government counties (20), all towns and municipalities with population superior to 10.000 inhabitants as first level units of local self-government (74) and regional and local development agencies (29). The questionnaires were sent between April and June 2014, in three rounds (first and third round as online questionnaires and the second round by regular post) to the heads of the organisations asking them to fill in the questionnaire or to delegate it to the person who is responsible for performance measurement system in their organisation.

In order to assess whether local units measure outputs, outcomes, efficiency and cost-effectiveness the respondent were ask to indicate the extent

11 For the use of performance measurement in the strategic management process, s. Poister (2013, pp. 162-166).

Of course, during the strategic planning process information on other performance dimensions as well as on quality are need (for example, information on citizens' satisfaction). However, this paper concentrates on the four selected performance dimensions since, as indicated by Siegel \& Summermatter (2008), outputs and outcomes are the most used performance dimensions and efficiency and cost-effectiveness deal with outputs and outcomes as well. 
in which their organisation measures each of these performance dimensions on a four point Liker-type scale. ${ }^{12}$

In order to establish the stage of strategic management development, the respondents were asked a series of questions on strategic planning and management practice. ${ }^{13}$

The received data are analysed with the methods of data inspection and descriptive statistics using Statistical Package for the Social Sciences 20.0 and MS Excel. In addition, 12 semi-structured interviews with heads of the organisations or civil servants responsible for performance or quality measurement have been conducted. ${ }^{14}$

Looking comparatively, Poister and Streib (2005) have analysed the state of development of strategic planning and management in USA municipalities with over 25,000 inhabitants. In their research, they have utilised also the Vizant and Vizant's (1996) categorisation of strategic management development; and, among other, they have examined the relationship of strategic planning/ management and performance measurement. However, Poister and Streib do not differentiate between various performance dimensions and extent of their measurement. Since in this paper the Vizant and Vizant's (1996) categorisation has been modified, a different approach in operationalisation of strategic management process has been applied, but the basic results of both researches can be compared.

\subsection{Research Results}

The total turnout to the questionnaire was 39.5\% (100 responses) and the distribution was even between the groups of organisations (50 central and 50 local organisations).

Performance measurement is not highly implemented in Croatia. Only outputs are being measured to a greater extent, while all other performance dimensions are being rather neglected with the majority of organisations measuring outcomes, efficiency and cost-effectiveness only sporadically or not at all (Table 1). The difficulties in the measurement of other performance dimensions have being proven also during the interviews with respondents who state, for example, that they 'do not measure outcomes since it is hard to make them measurable'. ${ }^{15}$

12 S. Appendix 1. For examples on research methodology on performance measurement, s. especially Van Dooren (2006); Foltz et al. (2009).

13 S. Appendix 1.

14 As the research has been conduct as part of PhD dissertation, details on methodology, questionnaire and results can be found in Manojlović (2014).

15 More on performance measurement in Croatian public administration, with particular emphasis on local self-government, s. Vitezić (2007) and Manojlović (2016a, 2016b). 
Table 1. Performance dimensions measurement

\begin{tabular}{|l|c|c|c|c|}
\hline $\begin{array}{l}\text { Performance } \\
\text { dimension /extent } \\
\text { of measurement }\end{array}$ & $\begin{array}{c}\text { Outputs } \\
(\%)\end{array}$ & $\begin{array}{c}\text { Outcomes } \\
(\%)\end{array}$ & $\begin{array}{c}\text { Efficiency } \\
(\%)\end{array}$ & $\begin{array}{c}\text { Cost- } \\
\text { effectiveness } \\
(\%)\end{array}$ \\
\hline Never & 12.1 & 20.0 & 27.9 & 47.8 \\
\hline Sporadically & 21.2 & 35.8 & 36.6 & 27.8 \\
\hline To a greater extent & 47.5 & 27.4 & 25.8 & 16.7 \\
\hline Systematically & 19.2 & 16.8 & 9.7 & 7.8 \\
\hline
\end{tabular}

Source: Author

As for strategic management, the Figure 1 shows that 77 (77\%) of organisations responding to the questionnaire have strategic plans, but only 50 of them have reports on strategic plan execution ${ }^{16}$, which is an initial indication that at least half of organisations do not enter into the second stage of strategic management development since the monitoring and evaluation of strategic plan implementation is missing.

Figure 1. Number of organisations having certain types of documents ${ }^{17}$

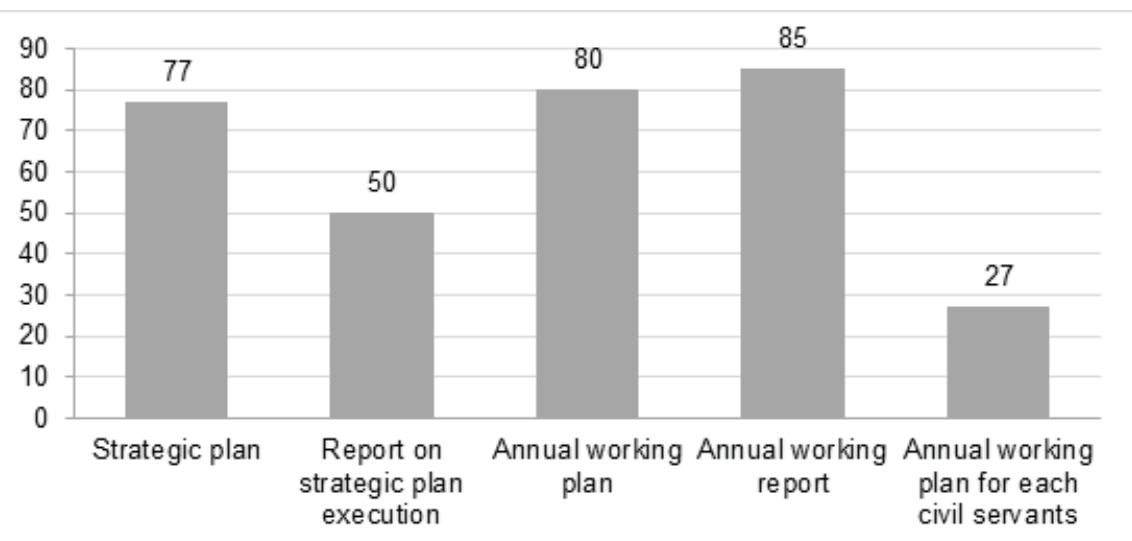

Source: Author

16 These reports might be prepared at the end of each year or at the end of entire strategic planning cycle. In this research such a distinction was not made, because the focus is on existance or non-existance of such a document.

17 The question could be why the existence of annual reports on the work of individual civil servants' is not included in the research. It is excluded since the empirical research is conducted in Croatian public administration where there is a legal obligation for state (Law on Civil Servants (Official Gazette, 92/05, 142/06, 77/07, 107/07, 27/08, 34/11, 49/11, 150/11, 34/12, 49/12, 37/13, 38/13, 01/15, 138/15)) and local civil servant (Law on Civil Servants in Local and Regional Self-Government, Official Gazette, 86/08, 61/11) to receive marks (assessment) at the end of the year. However, these marks (assessments) are not connected with organisational plans and do not stem from individual working plans (s. Parizek, 2009, p. 9; Marčetić, 2009, pp. 91-92). Thus, the inclusion of such question might compromise the results since most respondents would indicate that they have annual reports (meaning marks) and this would indicate that the performance of civil servant is being monitored, although this is not the case. Thus, in Croatian circumstance this element has been excluded, although theoretically it should be included. 
Furthermore, only 56 organisations use performance indicators in their strategic plans, and just 44 thereof use indicators in their reports on strategic plan execution which is a further proof that the monitoring stage is weak (Figure 2). The number of organisation having annual working plans and annual working reports is bigger than those having strategic plans, which points to the fact that strategic plan is not the leading document and that working plans do not stem from it. This indicates again that the second stage of strategic management development has not been achieved by the majority of organisations. A further testimony is the fact that only 37 organisations have their annual working plans completely connected with strategic plans (Figure 3).

Figure 2. Number of organisations having performance indicators in their documents

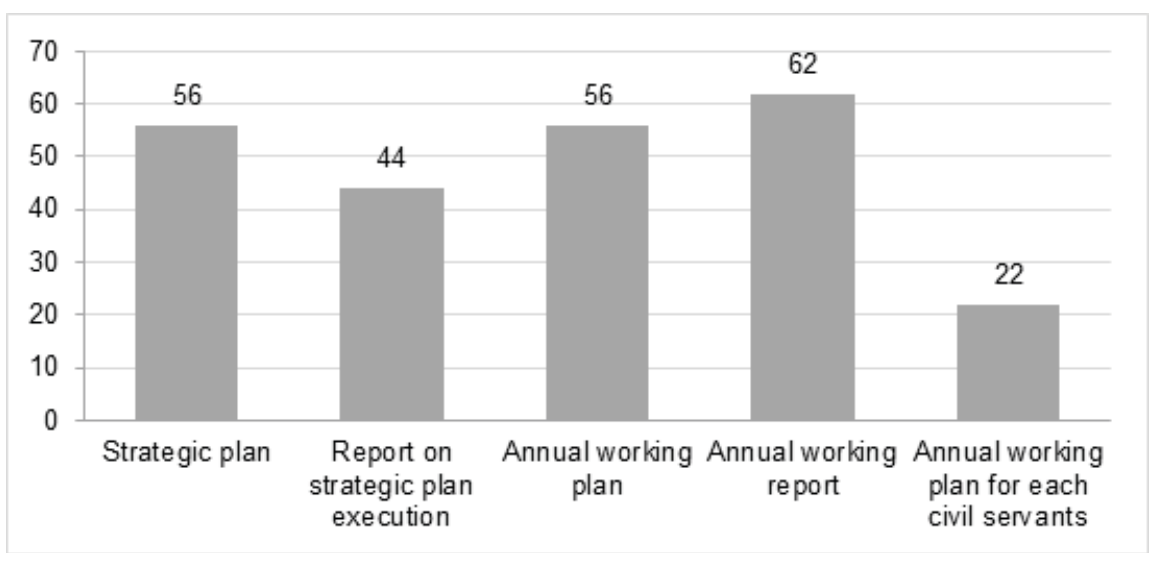

Source: Author

Figure 3. Number of organisations having annual working plans connected with strategic plans

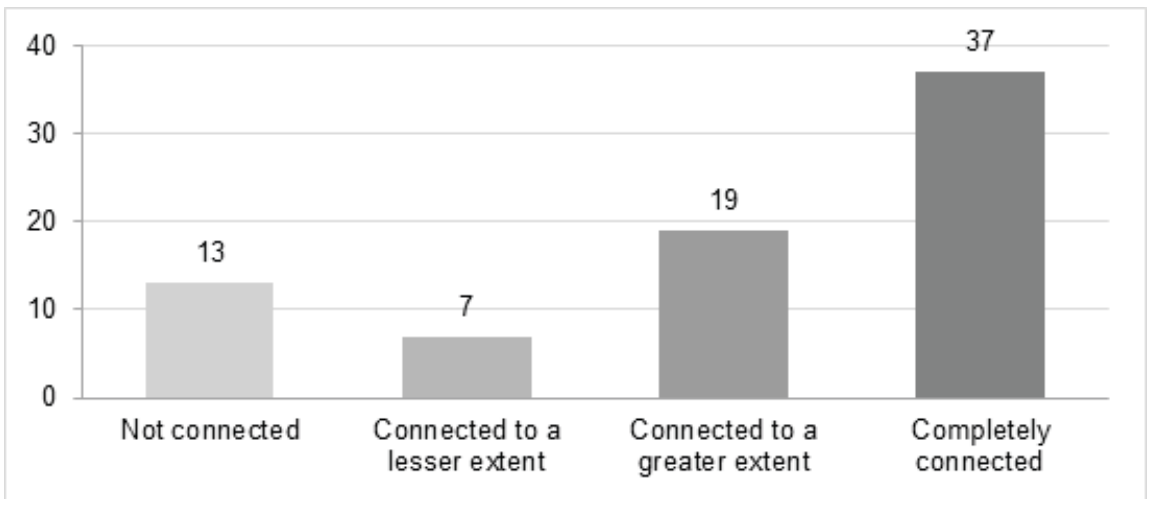

Source: Author 
The situation is similar when looking at the number of organisations having their budget connected to strategic plan: again only 30 organisations have done so completely (Figure 4).

Figure 4. Number of organisations having their budget connected to strategic plan

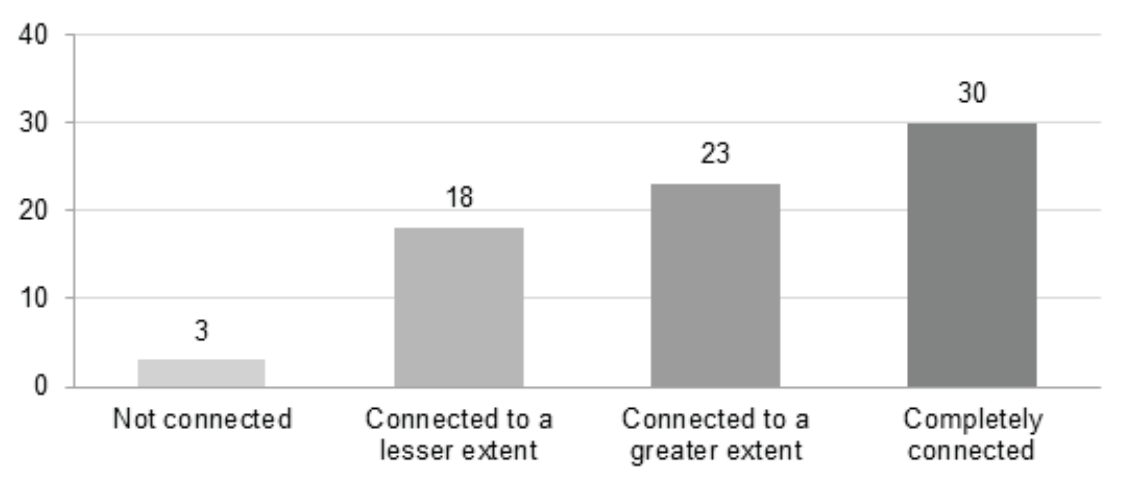

Source: Author

However, the biggest problem is the fact that the work of individual civil servants is not being measured. Namely, only 6 organisations of those responding to the questionnaire have civil servants' annual working plan completely connected with strategic plan (Figure 5).

Figure 5. Number of organisations having their budget connected to strategic plan

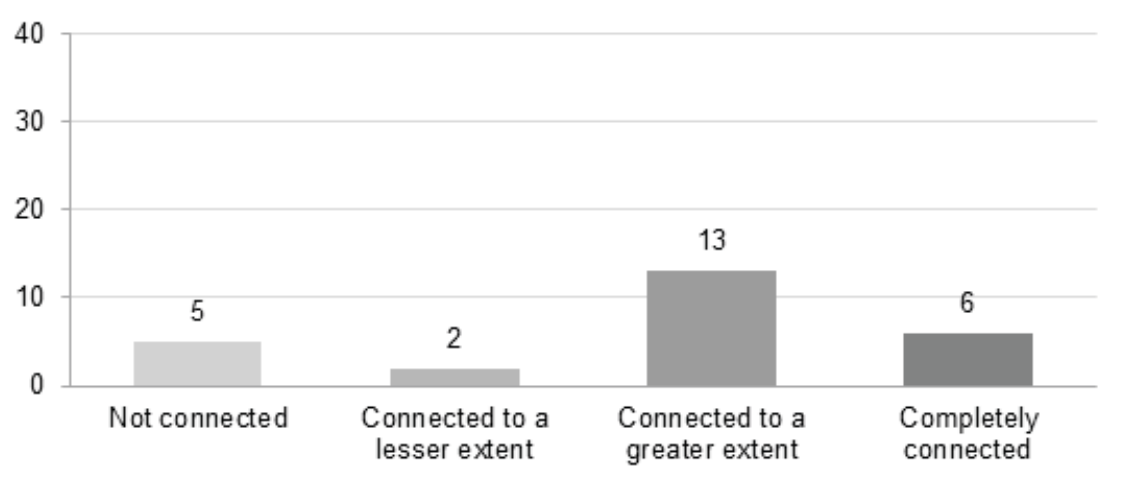

Source: Author

The data presented so far signalise that there are approximately $30 \%$ of organisations, which could be classified as entering into the second stage of strategic management development. This is further established by looking at the answers the respondents gave to the questions whether there are regular senior staff meetings in which the execution of strategic plans is being examined and whether the strategic plan is taken into consideration in the decision-making process. It is encouraging that 33 organisations held those meeting more than twice a year and in 41 organisations the decisions 
are very often or always based on their strategic plan. This indicates that those organisations, which are able to connect their strategic plans to annual working plans and budget, meaning getting the strategic plan 'to work', see the benefits of this process. This is confirmed also in the interviews during which the respondents coming from organisations, which classify for the higher stages of strategic management development have stated that 'strategic plan has facilitated and improved our operational planning, making the goals comprehensive and understandable'.

Figure 6. Regularity of meeting on strategic plan execution (number of organisations)

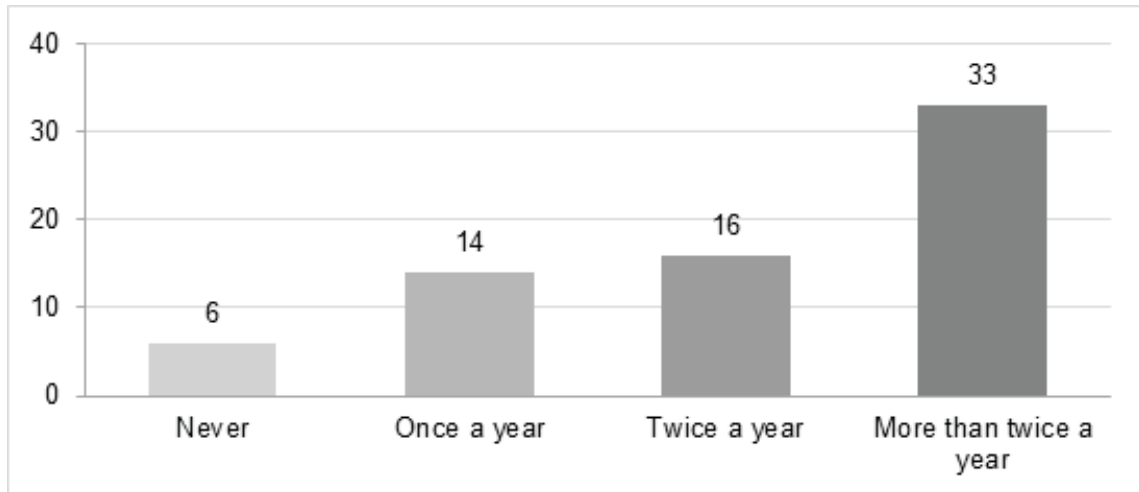

Source: Author

Figure 7. Strategic plan taken into consideration in the decision making process (number of organisations)

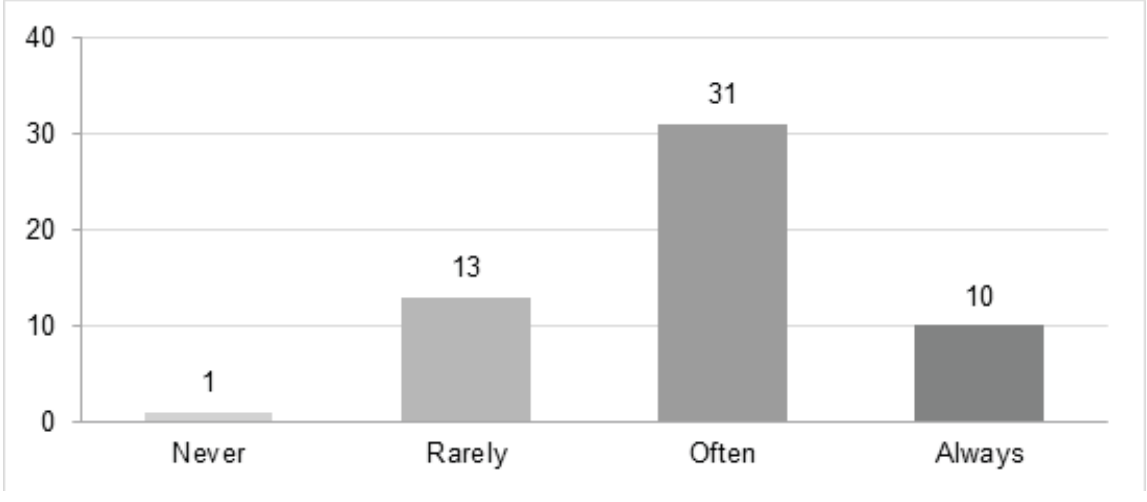

Source: Author

The Appendix 1 contains a list of elements, which need to be present in order for certain organisation to enter into different stages of strategic management. Following that categorisation, it is established that there are $18 \%$ of organisations, which do not have a strategic plan. Looking in its totality, Croatian public administration is still in the first phase of strategic management development. Strategic plans are being adopted; however, 
they are not being implemented and the majority of organisations do not know what to do with them (Table 2).

Table 2. Classification of organisations according to the stage of strategic management development

\begin{tabular}{|l|c|c|c|c|}
\hline Category & $\begin{array}{c}\text { No strategic } \\
\text { plan }\end{array}$ & Strategic plan & $\begin{array}{c}\text { Strategic } \\
\text { planning }\end{array}$ & $\begin{array}{c}\text { Strategic } \\
\text { management }\end{array}$ \\
\hline $\begin{array}{l}\text { Total } \\
\text { organisations }\end{array}$ & $18(18 \%)$ & $41(41 \%)$ & $31(31 \%)$ & $10(10 \%)$ \\
\hline $\begin{array}{l}\text { Central state } \\
\text { organisations }\end{array}$ & $7(14 \%)$ & $13(26 \%)$ & $22(44 \%)$ & $8(16 \%)$ \\
\hline $\begin{array}{l}\text { Local level } \\
\text { organisations }\end{array}$ & $11(22 \%)$ & $28(56 \%)$ & $9(18 \%)$ & $2(4 \%)$ \\
\hline
\end{tabular}

Source: Author

However, there are differences between central state administration and local level units. Namely, at the central state level, the State Budget Act (Official Gazette, 87/08, 136/12, 15/15) was amended in 2008 and it has created the obligation for all central state bodies to enact three-year strategic plans. The first generation of strategic plans was enacted for the 2010-2012 period. The Ministry of Finance plays a central role in this process since all the central state bodies are required to send their annual report to the Ministry. The Ministry also publishes guides on how to conduct the strategic planning process and indicates changes, which need to be adopted by these bodies. ${ }^{18}$ Obviously, because of the obligation introduced by the State Budget Act, central state administration is introduced with strategic planning process and $44 \%$ of organisation can be classified as entering into the second stage of strategic management development. However, the passing to the next stage, proper strategic management, is problematic since central state bodies have problems in connecting their annuals working plans with the strategic plan, budget and especially with the working tasks of single civil servants. As one respondent stated 'strategic planning has been formally introduced, we know it, but for now there is no more than that'.

The situation gets worst at the local level. Namely, according to the Law on Regional Development (Official Gazette, 147/14) only the counties (second level local units) and urban conglomerations, have the obligation to enact a development strategy. According to the State Budget Act, towns and municipalities are expected to enact the three years development plans which are connected to the budget, but these are not a throughout strategic plans. The lack of legal requirement can be the explanation why $78 \%$ of organisations either do not have a strategic plan or they are still in the very first stage of strategic management development. Most of the respondents state they have their strategic plans because someone required and said to do so, but these plans are still not the guiding documents. Thus, it is possible to say that at the local level, strategic plan are mostly a 'show out' documents, not used for precise purposes.

18 Availabile at http://www.mfin.hr/hr/stratesko-planiranje 


\subsection{Testing the Hypothesis}

In order to test whether the stages of strategic management development have influence on performance measurement, the correlation analysis is being conducted. As the Table 3 shows, out of 64 possible correlations, 46 are statistically significant and positive, which means there is a positive correlation between strategic management and performance measurement. In the remaining cases the correlation is weak, so it not possible to speak about real correlation. This is particularly visible in the case of cost-effectiveness. Since this is the least measured performance dimension, there are also the least correlations. However, the data show that the connection between strategic plan and budget is the most determinant factor for cost-effectiveness measurement.

Table 3. Correlations between stages strategic management development and performance dimensions

\begin{tabular}{|l|c|c|c|c|}
\hline $\begin{array}{l}\text { Strategic management / Performance } \\
\text { dimensions }\end{array}$ & Results (O) & $\begin{array}{l}\text { Outcomes } \\
(\mathrm{O})\end{array}$ & $\begin{array}{l}\text { Efficiency } \\
(\mathrm{O})\end{array}$ & $\begin{array}{l}\text { Cost- } \\
\text { effective- } \\
\text { ness (O) }\end{array}$ \\
\hline Existence of strategic plan (B) & 0.14 & 0.093 & $0.289^{* *}$ & 0.135 \\
\hline Strategic plan contains indicators (B) & $0.310^{*}$ & $0.355^{* *}$ & $0.382^{* *}$ & 0.137 \\
\hline $\begin{array}{l}\text { Existence of report on strategic plan } \\
\text { execution (B) }\end{array}$ & $0.316^{* *}$ & $0.350^{* *}$ & $0.249^{*}$ & 0.109 \\
\hline $\begin{array}{l}\text { Report on strategic plan execution } \\
\text { contains indicators (B) }\end{array}$ & $0.567^{* *}$ & $0.386^{* *}$ & $0.425^{* *}$ & 0.265 \\
\hline $\begin{array}{l}\text { Meetings on strategic plan execution } \\
\text { (O) }\end{array}$ & $0.336^{* *}$ & $0.352^{* *}$ & $0.386^{* *}$ & 0.174 \\
\hline Existence of annual working plan (B) & $0.227^{*}$ & $0.234^{*}$ & 0.174 & -0.019 \\
\hline $\begin{array}{l}\text { Annual working plan connected to } \\
\text { strategic plan (O) }\end{array}$ & $0.581^{* *}$ & $0.533^{* *}$ & $0.561^{* *}$ & $0.364^{* *}$ \\
\hline $\begin{array}{l}\text { Annuals working plan contains } \\
\text { indicators (B) }\end{array}$ & $0.516^{* *}$ & $0.458^{* *}$ & $0.409^{* *}$ & $0.322^{* *}$ \\
\hline Existence of annual working reports (B) & 0.169 & 0.16 & 0.172 & 0.038 \\
\hline $\begin{array}{l}\text { Annual working reports connected to } \\
\text { strategic plan (B) }\end{array}$ & $0.417^{* *}$ & $0.373^{* *}$ & $0.532^{* *}$ & $0.341^{* *}$ \\
\hline $\begin{array}{l}\text { Annual working reports contain } \\
\text { indicators (B) }\end{array}$ & $0.431^{* *}$ & $0.445^{* *}$ & $0.455^{* *}$ & $0.288^{*}$ \\
\hline Budget connected to strategic plan (O) & 0.143 & $0.262^{*}$ & $0.297^{*}$ & $0.472^{* *}$ \\
\hline $\begin{array}{l}\text { Strategic plan taken into consideration } \\
\text { in the decision making process (O) }\end{array}$ & 0.263 & $0.401^{* *}$ & $0.353^{*}$ & $0.331^{*}$ \\
\hline $\begin{array}{l}\text { Existence of annual working plan and } \\
\text { program for individual civil servants (B) }\end{array}$ & $0.237^{*}$ & $0.300^{* *}$ & $0.292^{* *}$ & $0.278^{*}$ \\
\hline $\begin{array}{l}\text { Annual working plan and program for } \\
\text { individual civil servants connected with } \\
\text { strategic plan (O) }\end{array}$ & 0.354 & $0.498^{*}$ & $0.481^{*}$ & 0.227 \\
\hline $\begin{array}{l}\text { Annual working plan and program } \\
\text { for individual civil servants contains } \\
\text { indicators (B) }\end{array}$ & $0.693^{* *}$ & $0.694^{* *}$ & $0.443^{*}$ & 0.375 \\
\hline
\end{tabular}

Legend: * correlation significant with $p<0.05$ (2-sided); ** correlation significant with $p<0.01$ (2-sided); (B) - binary variables; $(\mathrm{O})$ - ordinal variables

Note: The correlations between binary and ordinal variables were calculated using Pearsons correlation coefficient, while the correlations between two sets of ordinal variables were calculated using Spearman correlation coefficient.

Source: Author 
The strongest correlation can be seen between outcomes measurement and existence of annual working plan for individual civil servant with indicators. Since the public sector has to be oriented towards long-term outcomes (Bouckaert \& Halligan, 2008, p. 16), this can be used as a proof that the highest stage of strategic management is the one assuring outcomes measurement.

Altogether, the data signify that an organisation in which greater number of strategic management components are contained which by the consequence means that it is in a higher stage of the strategic management development, measures a greater number of performance dimensions and thus the hypothesis can be considered to be confirmed.

\section{Discussion}

The research results clearly show there is a connection between performance measurement and strategic planning and management.

Furthermore, the data show there are great differences between central state organisations and local units in Croatia. There are two possible explanations for this state of affairs. Firstly, central state organisations are required by the State Budget Act to enact strategic plans and submit regular reports on their implementation to the Ministry of Finance, which prepares guidance for the next strategic planning cycle. Local units do not have such guidance and are not required to submit such reports, which reduce the pressure to dive into the strategic management process. This brings to the conclusion that in the countries like Croatia, which are characterised by a strong procedureoriented culture and public management is mostly procedure/rules and not performance oriented, ${ }^{19}$ new managerial instruments need to be legally introduced in order to have the chance of being implemented. Second, it means that organisations need to have an institutionalised form of help and guidance in order to be able to implement these instruments.

The results show that the connection of strategic plans with annual working plans is one of the three elements, which stimulate the measurement of all performance dimensions. It means that the connections of goals, which are being measured on the operational level with the larger, strategic goals, stimulates the performance measurement process. In Belgium context, Van Dooren (2005, p. 379) has proven that the decoupling of performance indicators from the organisational objectives is nota hindrance for performance measurement adoption. ${ }^{20}$ Although this research has not examined the relationship between performance indicators and organisational objectives,

19 Halachmi and Bouckaert (1996, p. 4) state that there are two basic postures of government management: those process and those results oriented. This was already emphasised by Luhmann (1992, p. 120, in Koprić, 1999, p. 315) who has identified two types of programmes; the purposeful one, which are oriented towards goal attainments; and conditional one, which have the 'if-then' form, and the procedure has precedence over final results.

20 But it is a hindrance for the use of performance information ('performance measurement implementation'). 
the overall data seem to indicate that in Croatian circumstances any sort of decoupling could bring to the abandonment of measurement.

While outputs, outcomes and efficiency are often used performance dimensions, cost-effectiveness is difficult to measure. However, its measurement is growing in importance (s. Hatry, 2006, p. 23) and these results show that the most important factor for cost-effectiveness measurement is the connection between strategic plan and budget.

One point for the discussion might be whether it is the strategic management process that influences the performance measurement, or it is the other way round. Because of the obligation stemming from the State Budget Act as well as Law on Regional Development and the use of EU funds, ${ }^{21}$ in the Croatian public administration strategic planning is far more known than the operational performance measurement, which could mean that it is exactly through strategic planning process that the organisations are acquiring knowledge on new managerial instruments and developing further processes.

The importance of strategic planning and management for performance measurement is proven also in Estonia, where Nomm and Randma-Liiv (2012, p. 873) state that poor strategic planning capacity can affect the outcome of performance measurement initiatives and produce deficient performance indicators. In Lithuania, there is a clear connection between strategic planning and performance management since the process formally called 'strategic planning' includes all stages of managing strategic and operational performance and thus Nakrošiš (2008, p. 59) calls the entire process performance management (s. Nakrošiš, 2008).

The results from USA municipalities with over 25,000 inhabitants show that 20 years after the introduction of strategic planning and management in USA local governments, $56 \%$ of municipalities do not enter into the Vizant and Vizant's (1996) strategic management category but $44 \%$ of local units are able to conduct the entire strategic planning process. In addition, the research shows that local units have problems of linking performance measurement to strategic plans and thus creating a comprehensive strategic management process (Poister \& Streib, 2005). This is in line with theoretical critics of strategic planning and management, which state that it is hard to put strategic plans into action. Among other, this can happen because of the opposition coming from the employees or resistance among the managers (Poister \& Streib, 2005, p. 46). When these results are compared to $4 \%$ of Croatian local units entering into strategic management stage and only $18 \%$ entering into the strategic planning stage, it shows that there is a long way ahead of Croatia. On the positive side, strategic planning/management as well as performance measurement are a complete novelty in Croatia so there is a room for improvement.

21 One of the basic principles of EU funds is the programming principle and the coordination of all strategic documents (s. Đulabić, 2007). 


\section{Conclusion}

The basic purpose of this paper is to examine whether there is a connection between the stages of strategic management development and the measurement of greater number of performance dimensions. Examining the answers to the questionnaire given by $40 \%$ of public organisations in Croatian central and local public administration, there are strong indications that strategic management and performance measurement are positively correlated and that the development of strategic management influences the number of performance dimensions measured by public organisations. These findings open the space for further researches, which could concentrate on detailed examinations of factors influencing strategic management implementation and development, specifically in the context on transitional countries.

In Croatian circumstances, special attention should be devoted to local level organisations, which need to have clear guidance and help on how strategic planning and management process should be conducted. Apart from that, attention should be placed on connecting strategic plans with annual working plans and with individual civil servants working plans since it is proven that the connection of strategic goals with operational plans stimulates the measurement of all performance dimensions, including cost-effectiveness.

Strategic management, as well as performance measurement and management, are long-term processes and it takes time for an organisation to adapt to their full implementation. However, the future of public management points to the necessity of linking strategic management with performance measurement and management (Poister, 2010), so greater attention should be placed on examining their interrelations.

Romea Manojlović, PhD, is an assistant professor at the Chair of Administrative Science at the Faculty of Law, University of Zagreb. She is the executive editor of the international scientific journal Croatian and Comparative Public Administration and a member of the Croatian Institute of Public Administration. Her areas of interest include public management, local self-government, European administrative space and human resources management. 


\section{References}

Bouckaert, G. \& Halligan, J. (2008). Managing performance: International comparisons. New York, USA: Routledge, Taylor \& Francis Group.

Boyne, G. (2010). Strategic planning. In R. Ashworth, G. Boyne \& T. Entwistle (Eds.), Public service improvement - Theories and evidence (pp.60-77). Oxford, UK: Oxford University Press.

Bryson, J. M. (1995). Strategic planning for public and nonprofit organizations: A guide to strengthening and sustaining organizational achievement. San Francisco, USA: Jossey-Bass Publishers.

Đulabić, V. (2007). Regionalizam i regionalna politika [Regionalism and Regional Policy]. Zagreb, Croatia: Društveno veleučilište u Zagrebu.

Folz, D., Reem Abdelrazek, H. \& Chung, Y. (2009) The adoption, use, and impacts of performance measures in medium-size cities progress toward performance management. Public Performance \& Management Review, 33(1), 63-87. doi: 10.2753/PMR1530-9576330103

Gruening, G. (2001). Origin and theoretical basis of new public management. International Public Management Journal, 4(1), 1-25. doi: 10.1016/S1096-7494(01)00041-1

Hatry, H. P. (2006). Performance measurement - Getting results. Washington D.C., USA: The Urban Institute Press.

Halachmi, A., \& Bouckaert, G. (1996). Introduction: Performance appraisal and Rubik's cube. In A. Halachmi \& G. Bouckaert (Eds.), Organizational performance and measurement in the public sector. Toward service, effort and accomplishment reporting (pp. 1-10). Westport, USA: Praeger.

Koprić, I. (1999). Struktura i komuniciranje u upravnim organizacijama [Structure and communication in public organization]. Zagreb, Croatia: Pravni fakultet Sveučilišta u Zagrebu.

Koprić, I., Marčetić, G., Musa, A., Đulabić, V., \& Lalić Novak, G. (2014). Upravna znanost - javna uprava u suvremenom europskom kontekstu [Administrative science. Public administration in contemporary European context]. Zagreb, Croatia: Pravni fakultet Sveučilišta u Zagrebu.

Kreitner, R. (2008). Management (11th ed.). Boston, New York, USA: Houghton Mifflin Harcourt Publishing Company.

Manojlović, R. (2014). Utjecaj odabranih organizacijskih varijabli na mjerenje učinka upravnih organizacija [The Influence of selected organizational variables on performance measurement of public organization] (Unpublished doctoral dissertation). Zagreb, Croatia: Faculty of Law, University of Zagreb.

Manojlović, R. (2016a). Organisational size as a determinant of performance and quality measurement - Lessons for Croatian local governments. Croatian and Comparative Public Administration 16(2), 237-266.

Manojlović, R. (2016b). Upravljanje učinkom u hrvatskoj lokalnoj samoupravi [Performance management in Croatian local self-government]. In I. Koprić, J. Džinić, \& R. Manojlović (Eds.), Upravljanje kvalitetom i učinkovitošću u javnoj upravi [Quality and performance management in public administration] (pp. 69-96). Zagreb, Croatia: Institut za javnu upravu.

Marčetić, G. (2009). Prijedlozi za utemeljenje jedinstvenog službeničkog sustava u jedinicama lokalne i područne (regionalne) samouprave [Suggestions for the establishment of common cicil servant system in local and regional units]. In V. Đulabić (Ed.), Novo službeničko zakonodavstvo u lokalnoj samoupravi 
[New civil servants legislation in local self-government] (pp. 71-108). Zagreb, Croatia: Institut za javnu upravu.

McLaughlin, K., Osborne, S., \& Ferlie, E. (2002). New public management. Current trends and future prospects. New York, USA: Routledge.

Ministry of Finance. (2012). Smjernice za upravljačku odgovornosti [Guidance for managerial accountability]. Zagreb, Croatia: Sektor za harmonizaciju unutarnje revizije i financijske kontrole.

Nakrošiš, V. (2008). Reforming performance management in Lithuania: Towards results-based government. In G. B. Peters (ed.), Mixes, matches, and mistakes: New public management in Russia and the former Soviet republics (pp. 53-108). Budapest, Hungary: Institute for Local Government \& Public Service, Open Society Institute.

Nomm, K., \& Randma-Liiv, T. (2012) Performance measurement and performance information in new democracies. A study of the Estonian central government. Public Management Review 14(7), 859-879. doi: 10.1080/14719037.2012.657835

Parizek, M. (2010). Performance appraisal in the western Balkans: Overview and good practices from a capacity development perspective. UNDP Bratislava Regional Centre.

Perko Šeparović, I. (2006). Izazovi javnog menadžementa [Chalanges in Public Management]. Dileme javne uprave. Zagreb, Croatia: Golden marketing.

Poister, T. H (2003). Measuring performance in public and nonprofit organizations. San Francisco, USA: John Wiley \& Sons.

Poister, T. H. (2010). The future of strategic planning in the public sector: Linking strategic management and performance. Public Administration Review, 70(Special Issue s1), 246-254. doi: 10.1111/j.1540-6210.2010.02284.x

Poister, T. H., \& Streib, G. (1999). Strategic management in the public sector: Concepts, models, and processes. Public Productivity \& Management Review, 22(3), 308-325. doi: 10.2307/3380706

Poister, T. H., \& Streib, G. (2005). Elements of strategic planning and management in municipal government: Status after two decades. Public Administration Review, 65(1), 45-56. doi: 10.1111/j.1540-6210.2005.00429.x

Siegel, J. P., \& Summermatter, L. (2008). Defining performance in public management: A survey of academic journals. Paper presented at the EGPA Conference Rotterdam, Netherlands, 3rd September 2008.

Van Dooren, W. (2005). What makes organisations measure? Hypotheses on the causes and conditions for performance measurement. Financial Accountability \& Management, 21(3), 363-383. doi: 10.1111/j.0267-4424.2005.00225.x

Van Dooren, W. (2006) Performance measurement in the Flemish public sector: A supply and demand approach (Doctoral dissertation). Katholike University Leuven. Retrieved from http://soc.kuleuven.be/io/english/research/ publication/performance-measurement-in-the-flemish-public-sector-a-supplyand-demand-approach

Van Dooren, W., Bouckaert, G., \& Halligan, J. (2015). Performance management in the public sector. New York, USA: Routledge, Taylor \& Francis Group.

Vitezić, N. (2007). Beneficial effects of public sector performance measurement. Uprava/Administration, V(2), 7-27. 
Romea Manojlović

\section{Legal sources}

Law on Civil Servants. Official Gazette, 92/05, 142/06, 77/07, 107/07, 27/08, $34 / 11,49 / 11,150 / 11,34 / 12,49 / 12,37 / 13,38 / 13,01 / 15,138 / 15$.

Law on Civil Servants in Local and Regional Self-Government. Official Gazette, 86/08, 61/11.

Law on Regional Development. Official Gazette, 147/14.

State Budget Act. Official Gazette, 87/08, 136/12, 15/15. 


\section{Appendix 1. Coding of Performance Measurement and Stages of Strategic Management Development}

\begin{tabular}{|c|c|c|}
\hline Category & Indicators & \\
\hline Results & $\begin{array}{l}\text { - Degree of } \\
\text { measurement existing } \\
\text { in the organisation }\end{array}$ & $\begin{array}{l}\text { a) Never, b) Sporadically, c) To a greater extent, } \\
\text { d) Systematically, e) Does not know }\end{array}$ \\
\hline Outcomes & $\begin{array}{l}\text { - Degree of } \\
\text { measurement existing } \\
\text { in the organisation }\end{array}$ & $\begin{array}{l}\text { a) Never, b) Sporadically, c) To a greater extent, } \\
\text { d) Systematically, e) Does not know }\end{array}$ \\
\hline Efficiency & $\begin{array}{l}\text { - Degree of } \\
\text { measurement existing } \\
\text { in the organisation }\end{array}$ & $\begin{array}{l}\text { a) Never, b) Sporadically, c) To a greater extent, } \\
\text { d) Systematically, e) Does not know }\end{array}$ \\
\hline $\begin{array}{l}\text { Cost- } \\
\text { effectiveness }\end{array}$ & $\begin{array}{l}\text { - Degree of } \\
\text { measurement existing } \\
\text { in the organisation }\end{array}$ & $\begin{array}{l}\text { a) Never, b) Sporadically, c) To a greater extent, } \\
\text { d) Systematically, e) Does not know }\end{array}$ \\
\hline \multirow{3}{*}{$\begin{array}{l}\text { Stages of } \\
\text { strategic } \\
\text { management } \\
\text { development }\end{array}$} & $\begin{array}{l}\text { - STRATEGIC PLAN } \\
\text { STAGE }\end{array}$ & $\begin{array}{l}\text { - Existence of strategic plan } \\
\text { a)Yes, b) No }\end{array}$ \\
\hline & $\begin{array}{l}\text { - STRATEGIC PLANNING } \\
\text { STAGE }\end{array}$ & $\begin{array}{l}\text { - Strategic plan contains indicators } \\
\text { a) Yes, b) No, c) Does not know } \\
\text { - Existence of report on strategic plan execution with } \\
\text { indicators } \\
\text { a)Yes, b) No, c) Does not know } \\
\text { - Meetings on strategic plan execution } \\
\text { a) Never, b) Once a year, c) Twice a year, } \\
\text { d) More then twice a year, e) Does not know } \\
\text { - Annual working plan connected to strategic plan } \\
\text { a) No, b) To a lesser extent, c) To a greater extent, } \\
\text { d) Completely connected, e) Does not know } \\
\text { - Annual working reports connected to strategic plan } \\
\text { a) Yes, b) No, c) Does not know }\end{array}$ \\
\hline & $\begin{array}{l}\text { - STRATEGIC } \\
\text { MANAGEMENT STAGE }\end{array}$ & $\begin{array}{l}\text { - Budget connected to strategic plan } \\
\text { a) No, b) To a lesser extent, c) To a greater extent, } \\
\text { d) Completely connected, e) Does not know } \\
\text { - Strategic plan taken into consideration in the } \\
\text { decision making process } \\
\text { a) Never, b) Rarely, c) Often, d) Always, } \\
\text { e) Does not know } \\
\text { - Existence of annual working plans and programs of } \\
\text { individual civil servants } \\
\text { a) Yes, b) No, c) Does not know } \\
\text { - Annual working plans and programs for individual } \\
\text { civil servants connected with strategic plan } \\
\text { - a) No, b) To a lesser extent, c) To a greater extent, } \\
\text { d) Completely connected, e) Does not know } \\
\text { - Annual working plans and programs for individual } \\
\text { civil servants contains indicators } \\
\text { a) Yes, b) No, c) Does not know }\end{array}$ \\
\hline
\end{tabular}

Source: Author 
POVZETEK

\subsection{Izvirni znanstveni članek}

\section{Strateško upravljanje in merjenje uspešnosti - ali sta povezana? Dokazi iz hrvaške javne uprave}

Članek obravnava povezavo med strateškim upravljanjem in merjenjem uspešnosti v javnem sektorju. Tako strateško načrtovanje kot tudi merjenje uspešnosti spodbuja upravna doktrina novega javnega upravljanja, ki se v javnem sektorju številnih držav izvaja že od začetka osemdesetih letih prejšnjega stoletja.

Ker se strateško načrtovanje in merjenje uspešnosti pogosto obravnavata ločeno, je namen članka raziskati njuno medsebojno povezanost. Članek tako izoblikuje tri faze strateškega razvoja upravljanja, ki temeljijo na opredelitvi strateškega upravljanja T. Poistra (2003) in štirih ravneh strateškega upravljanja po Vizantu in Vizantu (1996). Prva faza je v celoti sestavljena iz vzpostavitve strateškega načrta. Druga faza vključuje izvedbo celotnega procesa strateškega načrtovanja, medtem ko tretja faza predstavlja ustrezno strateško upravljanje, pri katerem je proračun organizacije povezan s strateškim načrtom in z vsemi sistemi za merjenje uspešnosti, vključno z oceno uspešnosti javnih uslužbencev.

$\checkmark$ članku se uspešnost razume kot doseganje pričakovanih donosov in rezultatov v zvezi s sredstvi, ki se uporabljajo za njihovo doseganje (uspešno in stroškovno učinkovito). Iz tega sledijo štiri dimenzije uspešnosti: donos, rezultati, uspešnost in stroškovna učinkovitost. Glavna hipoteza je, da so faze strateškega razvoja upravljanja v pozitivni korelaciji s številom dimenzij uspešnosti, izmerjenih s strani javnih organizacij.

Za preizkus navedene hipoteze so predstavljeni rezultati empiričnih raziskav, opravljenih v hrvaški javni upravi. Vprašalnik je bil poslan 253 osrednjim in lokalnim organizacijam, odzivnost je bila 39,5\%. Vsi rezultati so bili statistično analizirani, medtem ko so bili opravljeni tudi dodatni polstrukturirani intervjuji.

Rezultati so pokazali, da je merjenje uspešnosti na Hrvaškem zelo omejeno. Večina organizacij namreč v večjem obsegu meri samo donos, medtem ko so rezultati, uspešnost in predvsem stroškovna učinkovitost zanemarjeni. Dodatni intervjuji so potrdili težave pri merjenju teh dimenzij uspešnosti. Rezultati v primeru strateškega upravljanja namreč kažejo, da je $77 \%$ organizacij, ki so odgovarjale na vprašalnik, sprejelo strateške načrte, vendar ima le 56 \% organizacij poročila o izvedbi teh načrtov, kar je prvi pokazatelj, da več kot polovica organizacij ni dosegla druge faze strateškega razvoja upravljanja. To dodatno potrjuje število organizacij z letnimi delovnimi načrti, letnimi delovnimi poročili, proračuni in letnimi delovnimi načrti za 
posamezne javne uslužbence, ki so povezani s strateškim načrtovanjem. Gledano v celoti je hrvaška javna uprava še vedno v prvi fazi strateškega razvoja upravljanja. Vendar obstajajo razlike med osrednjo državno upravo in upravo na lokalni ravni. V osrednjo državno upravo se namreč uvaja proces strateškega načrtovanja in $44 \%$ organizacij je opredeljenih za vstop v drugo fazo strateškega razvoja upravljanja. Situacija se poslabšuje na lokalni ravni, kjer 78 \% organizacij nima strateškega načrta ali pa so še vedno v prvi fazi strateškega razvoja upravljanja.

Da bi preverili, ali faze strateškega razvoja upravljanja vplivajo na merjenje uspešnosti, je bila opravljena analiza korelacije, ki je pokazala, da je večina korelacij med elementistrateškega upravljanja in merjenja uspešnosti pozitivna in statistično pomembna. Tako rezultati potrjujejo hipotezo in nakazujejo, da je krepitev strateškega načrtovanja in upravljanja ena od glavnih spodbud za merjenje uspešnosti na Hrvaškem.

Predvsem je treba v danih okoliščinah posebno pozornost nameniti organizacijam na lokalni ravni, ki potrebujejo jasne smernice in pomoč v zvezi z izvajanjem strateškega načrtovanja in procesa upravljanja. Poleg tega je treba več pozornost nameniti povezovanju strateških načrtov z letnimi delovnimi načrti in z delovnimi načrti posameznih javnih uslužbencev, saj je dokazano, da povezovanje strateških ciljev z operativnimi načrti spodbuja merjenje vseh dimenzij uspešnosti, vključno s stroškovno učinkovitostjo. 